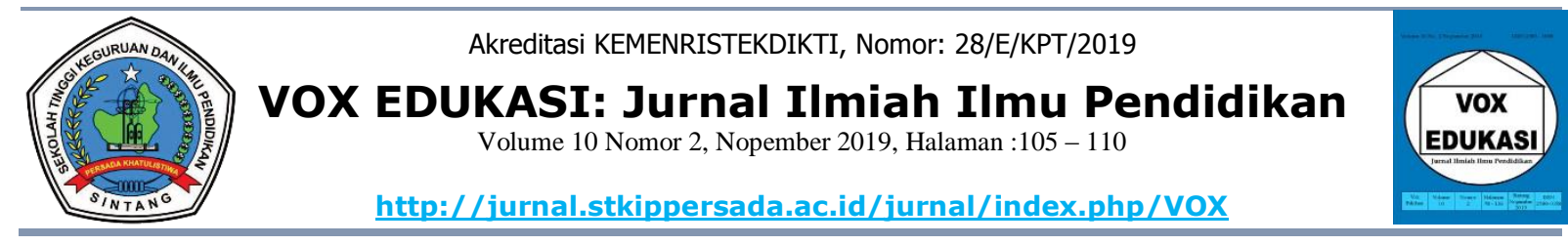

\title{
ANALISIS KEBUTUHAN BAHAN AJAR BERBASIS KEARIFAN LOKAL SEBAGAI PENUNJANG MATA KULIAH KAJIAN FIKSI
}

\author{
Saptiana Sulastri \\ Program Studi Pendidikan Bahasa dan Sastra Indonesia IKIP PGRI Pontianak \\ Email : saptianasulastri292@gmail.com
}

\begin{tabular}{l} 
INFO ARTIKEL \\
\hline Riwayat Artikel: \\
$\begin{array}{ll}\text { Menerima } & : 21 \text { Oktober } 2019 \\
\text { Revisi } & : 8 \text { Nopember } 2019 \\
\text { Diterima } & : 19 \text { Nopember } 2019\end{array}$
\end{tabular}

\section{Kata Kunci:}

kebutuhan bahan ajar, kajian

fiksi,kearifan lokal

\section{Keywords:}

the need for teaching materials, fiction studies, local wisdom

\section{Korespondensi: \\ Saptiana Sulastri \\ Program Studi Pendidikan \\ Bahasa dan Sastra Indonesia \\ IKIP PGRI Pontianak \\ Jalan Ampera No. 88 Pontianak \\ 78116, Email: \\ saptianasulastri292@gmail.com}

\begin{abstract}
ABSTRAK
Penelitian ini bertujuan untuk mendeskripsikan kebutuhan bahan ajar berbasis kearifan lokal sebagai penunjang mata kuliah kajian fiksi mahasiswa Program Studi Pendidikan Bahasa dan Sastra Indonesia IKIP PGRI Pontianak. Metode yang digunakan dalam penelitian ini adalah metode deskriptif kualitatif. Subjek yang dipilih mahasiswa pada salah satu kelas yang ada di Program Studi Pendidikan Bahasa dan Sastra Indonesia IKIP PGRI Pontianak. Instrumen pengumpul data adalah wawancara yang ditujukan kepada dosen dan mahasiswa. Untuk menganalisis kebutuhan bahan ajar berbasis kearifan lokal sebagai penunjang mata kuliah kajian fiksi menggunakan kualitatif yang diperoleh dari tanggapan dosen pengampu mata kuliah dan mahasiswa terkait dengan kebutuhan bahan ajar berbasis kearifan lokal sebagai penunjang mata kuliah kajian fiksi pada Mahasiswa Program Studi Pendidikan Bahasa dan Sastra Indonesia.
\end{abstract}

ABSTRACT
This study aims to describe the needs of teaching materials based on local
wisdom as supporting the fiction study subjects of the Indonesian Language and
Literature Education Study Program IKIP PGRI Pontianak. The method used
in this research is descriptive qualitative method. The subject chosen by students
in one of the classes in the Indonesian Language and Literature Education Study
Program IKIP PGRI Pontianak. Data collection instruments are interviews
aimed at lecturers and students. To analyze the needs of teaching materials
based on local wisdom as a support for fiction study subjects, using qualitative
obtained from lecturers and lecturers who are related to the needs of teaching
materials based on local wisdom as supporting fiction study subjects in
Indonesian Language and Literature Education Study Program Students.
(C)2019 LPPM STKIP Persada Khatulistiwa Sintang

\section{PENDAHULUAN}

Sistem pendidikan memiliki berbagai komponen pendukung. Salah satunya adalah bahan ajar. Bahan ajar merupakan alat bantu yang digunakan dosen menyampaikan pembelajaran kepada mahasiswa sesuai dengan
SK dan KD yang ditentukan. Sejatinya, bahan ajar yang baik tentu memperhatikan karakteristik dari bahan ajar yang dimaksudkan. (Muslich, 2010:34) mengemukakan kelayakan isi memiliki tiga indikator yang harus diperhatikan, yaitu kesesuaian materi dengan 
standar kompetensi dan kompetensi dasar, keakuratan materi, dan materi pendukung pembelajaran. Kelayakan penyajian meliputi teknik penyajian, penyajian pembelajaran, dan kelengkapan penyajian. Dalam hal kelayakan bahasa ada beberapa indikator yang harus diperhatikan, yaitu kesesuaian pemakaian bahasa dengan tingkat perkembangan siswa, pemakaian bahasa yang komunikatif, dan memenuhi syarat keruntutan dan keterpaduan alur berpikir. Kelayakan kegrafikan meliputi bentuk, desain kulit, dan desain isi.

Selain itu, ada aspek yang diperhatikan juga dalam penulisan buku ajar. Aspek-aspek tersebut adalah sebagai berikut. (1) aspek isi atau materi yaitu merupakan bahan pembelajaran yang harus spesifik, jelas, akurat, dan mutakhir dari segi penerbitan. Informasi yang disajikan tidak mengandung makna bias. Perincian materi harus mempertimbangkan keseimbangan dalam penyebaran materi, baik yang berkenaan dengan pengembangan makna dan pemahaman, pemecahan masalah, pengembangan proses, latihan dan praktik, dan tes keterampilan maupun pemahaman. (2) aspek penyajian materi yaitu aspek tersendiri yang harus diperhatikan dalam penyusunan buku, baik berkenaan dengan penyajian tujuan pembelajaran, keteraturan urutan dalam penguraian, kemenarikan minat dan perhatian siswa, kemudahan dipahami, keaktifan siswa, hubungan bahan, maupun latihan dan soal. (3) aspek bahasa dan keterbacaan yaitu sarana penyampaian dan penyajian bahan seperti kosakata, kalimat, paragraf, dan wacana. Aspek keterbacaan berkaitan dengan tingkat kemudahan bahasa (kosakata, kalimat, paragraf, dan wacana) bagi kelompok atau tingkatan siswa. (4) aspek grafika yaitu berkaitan dengan fisik buku seperti ukuran buku, kertas, cetakan, ukuran huruf, warna ilustrasi, dan lain-lain. Pada umumnya penulis buku tidak terlibat secara langsung dalam mewujudkan grafika buku, namun bekerjasama dengan penerbit.

Pemilihan jenis materi harus disesuaikan dengan kompetensi dasar dan standar kompetensi yang telah ditentukan. Selain itu, perlu diperhatikan pula jumlah atau ruang lingkup yang cukup memadai sehingga mempermudah mahasiswa dalam mencapai standar kompetensi. Dengan mengidentifikasi jenis-jenis materi yang akan diajarkan, maka guru akan mendapatkan kemudahan dalam cara mengajarkannya. Identifikasi jenis materi pembelajaran juga penting untuk keperluan mengajarkannya, sebab setiap jenis materi pembelajaran memerlukan strategi pembelajaran atau metode, media, dan sistem evaluasi/penilaian yang berbeda-beda. Misalnya metode mengajarkan materi fakta atau hafalan adalah dengan menggunakan "jembatan keledai", "jembatan ingatan" (mnemonics), sedangkan metode untuk mengajarkan prosedur adalah "demonstrasi".

Analisis terhadap relevansi bahan ajar dengan Kurikulum perlu dilakukan. (Dewi, 2009:15) menjelaskan bahwa analisis terhadap relevansi substansi buku bertujuan untuk mengetahui dan mendeskripsikan buku tersebut. Mengenai spesifikasi serta kualifikasi bahan-bahan dan informasi pembelajaran yang terdapat pada buku harusnya relevan dengan 
tujuan pembelajaran dan kurikulum. Cara yang paling mudah untuk menentukan jenis materi pembelajaran yang akan diajarkan adalah dengan jalan mengajukan pertanyaan tentang kompetensi dasar yang harus dikuasai mahasiswa.

Indonesia sendiri memiliki beragam kebudayaan dan kebudayaan ini tidak dapat dipisahkan dari masyarakatnya. Begitu pula dengan Pendidikan yang tidak dapat dipisahkan dengan kebudayaan. Pelaksanaan Pendidikan harus sesuai dengan kebudayaan bangsa Indonesia. Hal ini sejalan dengan UndangUndang Nomor 20 tahun 2003 tentang sistem Pendidikan Nasional "Pendidikan Nasional adalah Pendidikan yang berdasarkan Pancasila dan Undang-Undang Dasar Negara Republik Indonesia tahun 1945 yang berakar pada nilainilai agama, kebudayaan nasional Indonesia dan tanggap terhadap tuntutan perubahan zaman". Berdasarkan hal tersebut, kebudayaan nasional ini dibentuk dari kebudayaan daerah dan lokal yang di dalamnya terdapat kearifan lokal. Mahasiswa dikenalkan dengan kearifan lokal yang merupakan bagian dari kebudayaan.

Kebudayaan nasional adalah manifestasi kebudayaan daerah ditambah kebudayaan asing yang sesuai dengan kehidupan bangsa. Keanekaragaman kebudayaan daerah merupakan kebudayaan bangsa Indonesia yang tidak terwujud harganya. Pembangunan di bidang kebudayaan di Indonesia tentu tidak terlepas dari pemikiran dan usaha pembangunan dalam bidang sastra karena karya sastra merupakan cerminan kehidupan jiwa bangsa dari adat dan menjadi sitem sosial masyarakat.
Kalimantan Barat merupakan satu di antara provinsi di Indonesia yang memiliki keanekaragaman budaya. Keanekaragaman itu tentu tidak lahir dengan sendirinya, tetapi sebagai sebuah hasil cipta, rasa, karsa berbagai kelompok suku bangsa yang ada terutama suku Dayak dan Melayu. Berdasarkan pernyataan tersebut, jelas bahwa suku Dayak merupakan penduduk asli Kalimantan Barat yang memiliki kebudayaan tinggi sebab suku Dayak merupakan satu di antara suku bangsa yang pertama sekali membentuk kebudayaan di Kalimantan Barat.

Kearifan lokal merupakan identitas sebuah daerah. Salah satu provinsi di Indonesia yang memiliki banyak kearifan lokal adalah Kalimantan Barat, seperti tarian tradisional, makanan tradisional, kesenian, dan adat istiadat. Pengenalan kearifan lokal dapat melalui Mata Kuliah. Adapun salah satu Mata kuliah yang diajarkan di Perguruan Tinggi dan terdapat dalam kurikulum berbasis KKNI adalah Mata kuliah Kajian Fiksi. Mata kuliah ini bertujuan untuk memberikan kompetensi kepada mahasiswa untuk memahami, mengkaji, menjelaskan, dan menilai teks-teks fiksi. Saat ini, Pengajar dituntut untuk dapat mengembangkan materi yang disesuaikan dengan karakteristik ataupun potensi daerah tempat tinggal mahasiswa. Penyampaian materi dalam perkuliahan hendaknya menggunakan draf bahan ajar dan bahan pendamping yang disesuaikan dengan materi perkuliahan dan dikaitkan dengan keadaan sosial budaya di lingkungan mahasiswa 
tinggal, hal ini secara langsung dapat mendukung dalam penyampaian materi.

Namun, permasalahan yang sering dihadapi dosen berkenaan dengan bahan ajar adalah bahan ajar yang diberikan terlalu luas sehingga mahasiswa merasa kesulitan dalam belajar. Selain itu, materi yang disampaikan juga tidak kontekstual, dalam artian materi yang disampaikan tidak mencakup muatan kearifan lokal yang sesuai dengan daerahnya sehingga mahasiswa juga perlu pemahaman yang lebih untuk dapat menguasai materi yang disampaikan dalam bahan ajar tersebut. Maka dari itu, perlu dilakukan analisis kebutuhan bahan ajar menurut dosen pengampu mata kuliah kajian fiksi dalam melestarikan kearifan lokal.

Berdasarkan alasan yang telah dikemukakan, maka penelitian ini dianggap perlu untuk dilakukan karena dapat membantu dosen dalam menyampaikan materi dalam perkuliahan sebagai penunjang mata kuliah kajian fiksi pada mahasiswa program studi Pendidikan Bahasa dan sastra Indonesia IKIP PGRI Pontianak dan juga dapat melestarikan kearifan lokal yang ada di Kalimantan barat melalui pengembangan bahan ajar.

\section{METODE PENELITIAN}

Jenis penelitian yang digunakan dalam penelitian ini adalah penelitian deskriptif kualitatif. Penelitian yang dilakukan bertujuan untuk menganalisis kebutuhan bahan ajar menurut dosen pengampu mata kuliah kajian fiksi pada mahasiswa Program Studi Pendidikan Bahasa dan Sastra Indonesia IKIP PGRI Pontianak.
Adapun subjek penelitiannya adalah mahasiswa di salah satu kelas di Program Studi Pendidikan Bahasa dan Sastra Indonesia IKIP PGRI Pontianak. Teknik pengambilan data dengan menggunakan non tes dengan instrumen penelitian yang digunakan adalah wawancara. Esterberg (dalam Sugiyono 2012:319) mengemukakan beberapa macam wawancara yaitu wawancara terstruktur (structured interview), wawancara semi terstruktur (semistructured interview) dan wawancara tak terstruktur (unstructured interview).

Wawancara ditujukan kepada dosen pengampu mata kuliah Kajian Fiksi dan mahasiswa. Adapun pertanyaan yang diajukan terdiri dari 8 pertanyaan untuk dosen dan 4 pertanyaan untuk mahasiswa Program Studi Pendidikan Bahasa dan Sastra Indonesia.

Teknik analisis data penelitian dilakukan secara kualitatif diperoleh dari tanggapan dosen pengampu mata kuliah kajian fiksi dan mahasiswa terkait dengan kebutuhan bahan ajar yang digunakan.

\section{HASIL DAN PEMBAHASAN}

Hasil penelitian yang akan dikemukakan adalah mendeskripsikan kebutuhan bahan ajar menurut dosen pengampu mata kuliah kajian fiksi dan mahasiswa.

Berdasarkan hasil wawancara diperoleh informasi (1) Mata Kuliah Kajian Fiksi merupakan mata kuliah wajib pada Program Studi Pendidikan Bahasa dan Sastra Indonesia. (2) Sebelum melaksanakan perkuliahan, hal yang paling utama yang perlu 
dipersiapkan oleh dosen salah satunya adalah bahan ajar. (3) Bahan ajar disusun oleh dosen pengajar mata kuliah sebelum perkuliahan dimulai atau sebelum memasuki semester pembelajaran. (4) Pada saat proses pembelajaran, dosen pengampu mata kuliah menggunakan bahan ajar sebagai salah satu sumber belajar untuk mata kuliah kajian fiksi. Di awal semester, dosen telah menyebarkan bahan ajar kepada mahasiswa. Tujuan dari penyebaran bahan ajar ini, agar mahasiswa dapat dengan mudah mempelajari materi perkuliahan. Mahasiswa menyambut baik atas bahan ajar yang telah disebarkan tersebut. Ini terlihat dari peran aktif mahasiswa pada saat pertemuan perkuliahan, mahasiswa aktif dalam bertanya mengenai materi yang belum dipahami dari bahan ajar tersebut. (5) Setiap akhir perkuliahan, dosen selalu menginstruksi kepada mahasiswa untuk mempelajari bahan ajar sesuai dengan bab yang telah ditentukan. (6) Dosen pengampu mata kuliah kajian fiksi menyebutkan bahwa ada beberapa kendala dalam proses pembelajaran kajian fiksi, selama perkuliahan berlangsung. Salah satu kendala yang dimaksud adalah sulitnya mencari sumber referensi yang dapat memuat keseluruhan Standar Kompetensi (SK) serta Kompetensi Dasar (KD) yang telah ditentukan dalam mata kuliah Kajian Fiksi di IKIP PGRI Pontianak. Oleh karena itu, dosen pengampu mata kuliah perlu menyusun bahan ajar yang dianggap lengkap sesuai dengan kebutuhan dalam pengajaran untuk mencapai SK dan KD yang telah ditentukan. Penyusunan kembali bahan ajar ini pada dasarnya memerlukan cukup banyak waktu. (7) Keterbatasan waktu pengerjaan bahan ajar membuat dosen pengampu tidak dapat mengumpulkan banyak contoh mengenai jenis kajian sastra. (8) perlu adanya pengembangan bahan ajar yang memudahkan dosen dalam pemahaman materi secara mendalam.

Hasil wawancara dengan mahasiswa yaitu (1) mahasiswa terbantu dengan adanya bahan ajar. (2) peran bahan ajar sebagai pedoman dalam belajar dan memahami materi. (3) bahan ajar yang ada belum mengaitkan dengan kehidupan lokal. (4) mahasiswa memerlukan bahan ajar yang mudah dipahami dan membuat mahasiswa minat dalam membacanya.

Berdasarkan hasil wawancara yang peneliti lakukan dengan dosen pengampu mata kuliah diperoleh informasi bahwa dosen memerlukan bahan ajar yang sesuai dengan kebutuhan yaitu bahan ajar yang dianggap lengkap sesuai dengan kebutuhan dalam pengajaran untuk mencapai SK dan KD yang telah ditentukan. Kemudian, bahan ajar yang mudah dipahami mahasiswa adalah bahan ajar yang menyertai contoh kajian yang lebih kontekstual. Mahasiswa berharap bahan ajar yang akan diterapkan kelak bisa melibatkan seluruh mahasiswa dan dosen sebagai fasilitator sehingga mudah mengaitkan materi pembelajaran dalam kehidupan nyata. Oleh sebab itu, keberadaan bahan ajar pada kegiatan belajar dan mengajar sangat penting. Mahasiswa mengatakan bahwa bahan ajar yang digunakan belum mengaitkan dengan kehidupan sehari-hari. Hal ini membuktikan bahwa bahan ajar yang ada belum menampilkan komponen dari setiap materi 
yang dengan mengimplikasikannya dengan kehidupan sehari-hari. Dengan demikian, masih perlu dikembangkan bahan ajar yang sesuai dengan kebutuhan.

\section{SIMPULAN}

Berdasarkan hasil analisis data dan pembahasan, dapat disimpulkan bahwa analisis kebutuhan diperoleh melalui wawancara kepada dosen pengampu mata kuliah dan mahasiswa. Dari analisis kebutuhan diperoleh informasi bahwasanya kebutuhan bahan ajar yang diperlukan adalah bahan ajar yang sesuai SK dan KD serta kebutuhan mahasiswa. Diharapkan kedepannya, bahan ajar yang digunakan memerhatikan aspek kearifan lokal.

\section{DAFTAR PUSTAKA}

Dewi, Annisa A. (2009). Buku sebagai Bahan Ajar Sebuah Perbandingan Buku Teks Bahasa Inggris di Indonesia dan di Thailand. Sukabumi: CV Jejak.

Muslich, Mastur. (2010). Text Book Writing. Jogjakarta: Ar-ruz Media.

\begin{tabular}{|c|c|}
\hline $\begin{array}{r}\text { Sugiyono. }(2012) . \\
\text { Pendidikan }\end{array}$ & $\begin{array}{c}\text { Metode } \\
\text { Pendekatan }\end{array}$ \\
\hline $\begin{array}{l}\text { Kualitatif, } \\
\text { Alfabeta }\end{array}$ & dan $R \& D$. \\
\hline
\end{tabular}

